\title{
Foundered Lower Continental Crust in the Source of Group 2 Kimberlites
}

\author{
Chris Hatton \\ MSA Geoservices, Johannesburg, South Africa
}

Plate reconstructions link the 60-95 Ma group 1 kimberlites of southern Africa to the Shona hotspot in the southern Atlantic (Hartnady and le Roex, 1985). The group 2 kimberlites are older, between 105 and $200 \mathrm{Ma}$ and plate reconstructions for this period are poorly constrained. Hargraves (1989) found a significant shift in the palaeomagnetic south pole of the group 1 and group 2 kimberlites. This data requires that the African plate migrated $1700 \mathrm{~km}$ southward from 105 to $95 \mathrm{Ma}$. The resultant track joins the group 2 kimberlite track (Skinner, 1989) to the Namibian kimberlites which Davies et al. (2001) link to the Discovery hotspot. Both group 1 and group 2 kimberlites can therefore be related to a mantle reservoir sampled by a mantle plume. Reservoirs considered below are the subcontinental lithosphere, the MORB source, the transition zone, lower continental crust, ancient recycled continental crust, and depleted lower mantle.

\section{Subcontinental Lithosphere}

Becker and le Roex (2006) regard the mantle plume as a source of heat only, and relate the distinct chemistry of group 1 and group 2 kimberlites to two distinct types of clinopyroxene found in the lithosphere, in metasomatised lithospheric peridotites. For example, type 1 clinopyroxenes have higher $\mathrm{Nb} / \mathrm{Th}$ ratios than type 2 clinopyroxenes, matching the higher $\mathrm{Nb} / \mathrm{Th}$ ratio of group 1 kimberlites relative to group 2 kimberlites (Fig. 1). $\mathrm{Nb} / \mathrm{Th}$ ratios in the type 2 clinopyroxenes are 2 or less and are highly variable, while the $\mathrm{Nb} / \mathrm{Th}$ ratio in group 2 kimberlites cluster around 4 and are more coherent. Similarly, $\mathrm{Nb} / \mathrm{Th}$ ratios in group 1 kimberlites are far more tightly clustered than $\mathrm{Nb} / \mathrm{Th}$ ratios in type 1 clinopyroxenes (Fig. 1). The same pattern is observed for $\mathrm{Hf}$ and $\mathrm{Nd}$ isotope ratios, where kimberlites form tight clusters which deviate by +4 to $16 \Delta \varepsilon_{\mathrm{Hf}}$ units from the mantle array while Kaapvaal peridotites range to values above $100 \Delta \varepsilon_{\mathrm{Hf}}$ units from the mantle array (Nowell et al., 2004). The variable and incoherent isotope chemistry of the subcontinental lithosphere led Nowell et al. (2004) to reject this reservoir as a significant contributor to kimberlite magmatism, and to seek for a deeper source.

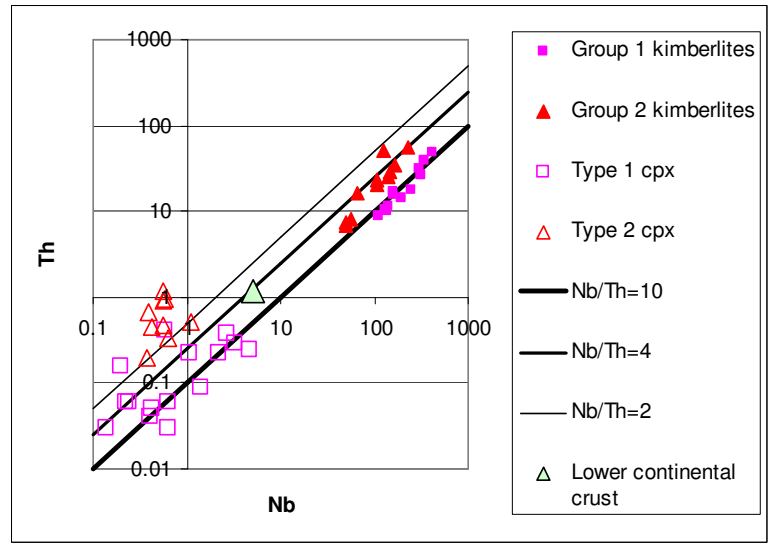

Fig. 1. $\mathrm{Nb}$ and Th contents of kimberlites, lithospheric clinopyroxenes and lower continental crust.

\section{MORB source}

The lithosphere is underlain by the asthenosphere which is connected to the source of Mid-Ocean Ridge Basalts. One characteristic of the MORB source is its low ${ }^{3} \mathrm{He} /{ }^{4} \mathrm{He}$ ratios, so the observation that some group 1 kimberlites have high ${ }^{3} \mathrm{He} /{ }^{4} \mathrm{He}$ ratios requires a yet deeper reservoir (Sumino et al., 2006; Tachibana et al., 2006).

In the standard model of two-layer mantle convection the base of the MORB source is at $660 \mathrm{~km}$ (Hofmann, 1997). Heat flow from the MORB source into the overlying lithosphere decreases as the thickness of the MORB source decreases, so that heat flow into thick continental lithosphere is lower than into thick continental lithosphere. The magnitude of this variation is large, too large to be accommodated by a MORB source with a base at $660 \mathrm{~km}$. Instead the base of the MORB source must lie at $410 \mathrm{~km}$, at the top of the transition zone (Hatton, 2008).

\section{Transition zone}

In isotope ratio arrays ocean island basalt converge to a focus zone, or FOZO, which is thought to represent the depleted lower mantle (Hart et al., 1992). The high ${ }^{3} \mathrm{He} /{ }^{4} \mathrm{He}$ source, referred to as $\mathrm{C}$ (Hanan and Graham, 1996) has average ${ }^{143} \mathrm{Nd} /{ }^{144} \mathrm{Nd}$ isotope ratios near 0.5129 , representing mantle which is distinctly less depleted than FOZO, where the average value is 
0.5131 (Hofmann, 1997). A reasonable location for $\mathrm{C}$ is therefore in the transition zone above the depleted lower mantle and below the MORB source. The $\mathrm{Sr}$ and $\mathrm{Nd}$ isotope ratios of $\mathrm{C}$ lie within the carbonatite box of Harmer and Gittins (1998) and are similar to the HIMU component which Smith (1983) associated with group 1 kimberlites. $\mathrm{C}$ is therefore a suitable source for group 1 kimberlite magmatism. Group 2 kimberlites have an enriched mantle, or EM signature (Smith, 1983) and must contain a contribution from another reservoir.

\section{Lower continental crust}

The enriched mantle signature in basalts of the Indian Ocean is referred to as the DUPAL anomaly, and has been linked to the delamination of lower continental crust during Gondwana breakup (Escrig et al., 2004). The track of the group 2 kimberlites places the Discovery hotspot at the site of Gondwana breakup at $188 \mathrm{Ma}$ so this is an attractive hypothesis. Delaminated lower continental crust may have contaminated the Discovery hotspot. This hypothesis receives support from the observation that lower continental crust has a $\mathrm{Nb} / \mathrm{Th}$ ratio of 4 , similar to that of group 2 kimberlites. Eclogites in the group 2 Roberts Victor kimberlite have bulk $\mathrm{TiO}_{2}$ contents which are too low for recycled oceanic crust (Hatton, 1978) and they could be samples of lower continental crust returned to surface via the Discovery hotspot.

Oxygen isotopes in Roberts Victor eclogites range from $\delta^{18} \mathrm{O}$ of 2 to 8 (Garlick et al., 1971). In the lower crust the range is from $\delta^{18} \mathrm{O}$ of 5 to 13 (Kempton and Harmon, 1992). By contrast low-chrome garnets associated with group 2 kimberlites have a restricted $\delta^{18} \mathrm{O}$ value of $5.59 \pm 0.18$ (Schulze et al., 2001). As is the case for the lithosphere, the variation in the isotope chemistry of lower continental crust is too great for this reservoir to be a significant contributor to kimberlite magmatism. A further problem is that the oldest group 2 kimberlite, Dokolwayo, was emplaced at 200 $\pm 5 \mathrm{Ma}$ (Allsopp and Roddick, 1984). Gondwana breakup commenced at least 20 to 40 million years after this (Duncan et al., 1997) so it is difficult to appeal to crustal delamination in explaining the enriched mantle signature of this particular kimberlite.

\section{Ancient recycled continental crust}

The $\delta^{18} \mathrm{O}$ value of $5.59 \pm 0.18$ that is associated with group 2 kimberlites (Schulze et al., 2001) falls within the range of 5.4 to 6.1 found in EM2 ocean island basalts (Eiler et al., 1997). The EM2 component is usually related to whole mantle convection which carries components from the continental crust to the deep mantle (Jackson et al., 2007). Continuous whole mantle convection cannot be reconciled with the strongly layered mantle proposed here. Whole mantle convection may have been a feature of the early earth only.

Boyet and Carlson (2005) demonstrated that an early enriched reservoir formed before $4.53 \mathrm{Ga}$, but after 4.5 $\mathrm{Ga}$ this reservoir was isolated. Isolation of this reservoir may be linked to the cessation of vigorous whole mantle convection. Terrestrial lead isotope evolution probably began at $4.45 \mathrm{Ga}$ (Rudnick and Goldstein, 1990) and this dates the end of vigorous whole mantle convection.

During vigorous whole mantle convection the mantle degassed and the outer layers of early earth were anhydrous. The current budget of volatile elements and noble elements is widely considered to have been added in a late veneer. The transition zone contains the water-rich minerals wadsleyite and ringwoodite, and hosts a large proportion of the earth's water. Once water was retained in the earth the transition zone became a discrete and separate reservoir, abruptly curtailing whole mantle convection.

The enriched mantle component in group 2 kimberlites is therefore ultimately related to continental crust which formed in the Hadean earth and accumulated at the base of the mantle. A large, very low velocity anomaly at the core-mantle boundary marks the site where this component is currently entrained in rising diapirs (Wen, 2006). These diapirs rise up to the transition zone, producing secondary diapirs.

The Cretaceous Group 1 kimberlites of southern Africa contain only a minor component of the deep enriched mantle. Their isotope chemistry is dominated by the $\mathrm{C}$ signature of the transition zone. By contrast the isotope chemistry of lamproites is dominated by the enriched mantle signature (Bell, 2006). Group 2 kimberlites are intermediate, with contributions from the enriched mantle reservoir at the base of the mantle and from the transition zone reservoir.

While the deep mantle reservoirs are the ultimate sources of kimberlite magmatism, it is the secondary diapirs rising from the transition zone that produce the hotspot tracks associated with particular kimberlite clusters, and it is the interaction between these secondary diapirs and the base of the lithosphere that yields the economic concentrations of diamonds that are associated with kimberlites.

\section{References}

Allsopp, H. L., Roddick, J. C., 1984, Rb-Sr and ${ }^{40} \mathrm{Ar}-{ }^{39} \mathrm{Ar}$ age determination on phlogopite micas from the pre Lebombo Group Dokolwayo kimberlite pipe. Special Publication of the Geological Society of South Africa, 13, 267-271.

Becker, M., and le Roex, A. P., 2006. Geochemistry of South African On- and Off-craton, Group I and Group II Kimberlites: Petrogenesis and Source Region Evolution. Journal of Petrology, 47, p. 673-703. 
Bell, K., Castorina, F., Rosatelli, G., and Stoppa, F., 2006, Plume activity, magmatism, and the geodynamic evolution of the Central Mediterranean. Annals of Geophysics, Supplement to volume 49, 357-371.

Boyet, M., Carlson, R. W., 2005, ${ }^{142} \mathrm{Nd}$ Evidence for early $(>4.53 \mathrm{Ga})$ global differentiation of the Silicate Earth. Science, 309, 576-581.

Davies, G. R., Spriggs, A. J., Nixon, P. H., 2001. A noncognate origin for the Gibeon kimberlite megacryst suite, Namibia: Implications for the origin of Namibian kimberlites. Journal of Petrology, 42, 159-172.

Duncan, R. A., Hooper, P. R., Rehacek, J., Marsh, J. S., Duncan, A. R., 1997. The timing and duration of the Karoo igneous event, southern Gondwana. Journal of Geophysical Research, 102, 18127-18138.

Eiler, J. M., Farley, K. A., Valley, J. W., Hauri, E. H., Craig, H., Hart, S. R., and Stolper, E. M., 1997. Oxygen isotope variations in ocean island basalt phenocrysts. Geochimica et Cosmochimica Acta, 61, 2281-2293.

Escrig, S., Capmas, F., Dupré, B., Allègre, C. J., 2004. Osmium isotopic constraints on the nature of the DUPAL anomaly from Indian mid-ocean-ridge basalts. Nature, $431,59-63$.

Garlick, G. D., MacGregor, I. D., Vogel, D. E., 1971, Oxygen isotope ratios in eclogites from kimberlites. Science, 172, 1025-1027.

Hanan, B. B., Graham, D. W., 1996. Lead and helium isotope evidence from oceanic basalts for a common deep source of mantle plumes. Science, 272, 991-995.

Hargraves, R. B., 1989. Paleomagnetism of Mesozoic kimberlites in southern Africa and the Cretaceous apparent polar wander curve for Africa. Journal of Geophysical Research, 94, 1851-1866.

Harmer, R. E., Gittins, J., 1998. The case for primary, mantle-derived carbonatite magma. Journal of Petrology, 39, 1895-1903

Hart, S. R., Hauri, E. H., Oschmann, L. A., Whitehead, J. A., 1992, Mantle Plumes and Entrainment: Isotopic Evidence. Science, 256, 517-520.

Hartnady, C. J. H., le Roex, A. P., 1985. Southern Ocean hotspot tracks and the Cenozoic absolute motion of the African, Antarctic, and South American plates. Earth Planetary Science Letters, 75, 245-257.

Hatton, C., 1978. The geochemistry and origin of eclogites from the Roberts Victor mine. Ph D thesis, University of Cape Town.

Hatton, C., 2008. Lithosphere thickness and diamond content of kimberlites. Extended abstract, 9IKC-A-00234.

Hofmann, A. W., 1997. Mantle geochemistry: the message from oceanic volcanism. Nature, 385, 219-229.

Jackson, M. G., Hart, S. R., Koppers, A. A. P., Staudigel, H., Konter, J., Blusztajn, J., Kurz, M., Russell, J. A., 2007. The return of subducted continental crust in Samoan lavas. Nature, 448, 684-687.

Kempton, P. D., Harmon, R. S., 1992. Oxygen isotope evidence for large-scale hybridization of the lower crust during magmatic underplating. Geochimica et Cosmochimica Acta, 56, 971-986.

Nowell, G. M., Pearson, D. G., Bell, D. R., Carlson, R. W., Smith, C. B., Kempton, P. D., Noble, S. R., 2004. Hf Isotope Systematics of Kimberlites and their Megacrysts: New Constraints on their Source Regions: Journal of Petrology, 45, 1583-1612.

Rudnick, R. L., Goldstein, S. L., 1990, The Pb isotopic compositions of lower crustal xenoliths and the evolution of lower crustal $\mathrm{Pb}$. Earth and Planetary Science Letters, v. 98 , p. $192-207$.

Schulze, D. J., Valley, J. W., Bell, D. R., and Spicuzza, M. J., 2001, Oxygen isotope variations in $\mathrm{Cr}$-poor megacrysts from kimberlite: Geochimica et Cosmochimica Acta, v. 65, p. 4375-4384.

Skinner, E.M.W.S., 1989. Contrasting group I and group II kimberlite petrology: towards a genetic model for kimberlites. Kimberlites and Related Rocks, vol. I, Their composition, occurrence, origin and emplacement; Proceedings of the Fourth International Kimberlite Conference; Geological Society of Australia, Special Publication 14, 528-544.

Smith, C. B., 1983. Pb, Sr and $\mathrm{Nd}$ isotopic evidence for sources of southern African Cretaceous kimberlites: Nature, 304, p. 51-54

Sumino, H., Kaneoka, I., Matsufuji, K., Sobolev, A. V., 2006. Deep mantle origin of kimberlite magmas revealed by neon isotopes. Geophysical Research Letters, 33, L16318, doi:10.1029/2006GL027144.

Tachibana, Y., Kaneoka, I., Gaffney, A., Upton, B., 2006. Ocean-island basalt-like source of kimberlite magmas from West Greenland revealed by high $3 \mathrm{He} / 4 \mathrm{He}$ ratios. Geology, 34, p. 273-276.

Wen, L., 2006. A compositional anomaly at the Earth's coremantle boundary as an anchor to the relatively slowly moving surface hotspots and as source to the DUPAL anomaly. Earth and Planetary Science Letters, 246, 138148. 